\title{
XII КОНГРЕС SIEF
}

\section{О. О. Микитенко}

21-25 червня 2015 р. у Загребі (Хорватія) відбувся ХІІ Конгрес Міжнародного товариства етнологів і фольклористів (SIEF). Проходив конгрес на базі факультету гуманітарних та суспільних наук Загребського університету (Хорватія). Безпосередню участь в організації та проведенні наукового заходу взяли співробітники Відділення етнології та культурної антропології університету, а також Інституту етнології і фольклористики Хорватської академії наук і мистецтв. Підтримку авторитетному міжнародному зібранню надали Міністерство науки, освіти та спорту Республіки Хорватія, муніципалітет Загреба, ряд міжнародних та національних організацій, засвідчивши роль і значення проведення конгресу у «наймолодшій» країні європейської спільноти - Хорватії.

Не випадково темою XII Конгресу SIEF було обрано «Утопії, дійсність, спадщина: етнографи для XXI століття». Сьогодні перед етнологією, культурною антропологією та фольклористикою стоять нові питання, а саме: як матеріалізуються утопії, реальність та спадщина, де і як вони взаємодіють, яким чином стають предметом наративного досвіду та культурної практики і чи допомагають культурне надбання та утопія нашому розумінню щоденних потреб і реалій - тут і зараз? Дати відповіді на ці та інші питання наука покликана, виходячи з соціальної та культурної динаміки, із контексту нового економічного, політичного, релігійного та культурного бачення ${ }^{1}$.

SIEF - найвпливовіше європейське етнологічне товариство - «перейшло» свій п’ятдесятирічний рубіж, і сьогодні, підкреслив на відкритті конгресу його голова Вальдемар Хафштейн (Університет Ісландіi), «вступає у другу половину свого першого сторіччя». Порівнюючи з часом проведення першого Міжнародного конгресу європейських етнологів у Парижі 1971 р., який було організовано директором Національного музею народного мистецтва і традицій (MNATP) професором Ж. Кюізіньє, теперішній науковий дискурс позначається антропоцентричною парадигмою аналізу та зазнає значних змін, коли до наукових досліджень залучається чимало нових тем, раніше визнані аспекти досліджень потребують уточнень. Водночас все актуальнішими стають проблеми, пов'язані із традиціями - у широкому розумінні - як повсякденним життям людей, міграційними процесами, культурною спадщиною тощо.

Паралельно із розширенням дослідного поля до наукової термінології входять нові терміни, зокрема vernacular на позначення 'народне, місцеве, загальновживане'. Принципами прагматики та комунікації окреслюються поняття «мобільної щоденної» (mobile everyday) етнографії та «етнографії непрофесіоналів» (lay ethnography), а також пара-етнографії (para-ethnography) ${ }^{2}$. Поряд із явищем «локального» вирізняється «транслокальне», «національне» доповнюється «транснаціональним» ${ }^{3}$; до уваги беруться не лише процеси міграцій, але й дифузій; явища диференціації доповнюються аналізом тотожностей; релігійні погляди розглядаються у контексті секуляризації свідомості та сучасної імагінології. При цьому незмінною залишається увага до проблем збереження традиції, але водночас iii творення, до наративу (у широкому культурологічному розумінні), до гендерних проблем, i, звичайно, всіх аспектів збереження культурного надбання, зокрема музеєфікації та архівування тощо.

Такі аспекти загалом характерні як для європейської, так і американської етнології. Сьогодні, як наголошують науковці, на новому етапі співробітництва знаходиться співпраця SIEF з Американським фольклорним товариством (AFS). Найстаріша асоціація американських фольклористів (заснована у 1888 р.) - професіоналів-етнологів, котрі досліджують фольклор не лише у США, але й в усьому світі (при цьому кожний восьмий член товариства не є американцем), видає щоквартальник «Journal of American Folklore» та проводить щорічні конгреси, останнім часом все більше співпрацюючи 3 європейськими колегами, влаштовуючи спільні наукові заходи тощо.

Насичена робота XII Конгресу SIEF проходила у різному форматі на кількох майданчиках студентського містечка: основні заходи - секційні засідання, показ фільмів, «круглі 
столи», засідання робочих груп, координаційні зустрічі були на факультеті гуманітарних та суспільних наук; там же у просторому фойє проходили презентації видань та книжкові виставки; щоранку (ще до початку секційних засідань) у студентському центрі, розташованому неподалік, із доповіддю виступав хтось із провідних науковців; урочисті церемонії відкриття та закриття конгресу відбувалися у приміщенні концертного залу імені В. Лисинського.

Відкриття конгресу, наприклад, передбачало офіційну, наукову та концертну частини. Учасників конгресу тепло привітав Президент SIEF B. Хафштейн та Голова місцевого комітету з проведення конгресу Я. Чапо. Прозвучали вітання від мера Загреба, від ректора Загребського університету, від декана факультету гуманітарних та суспільних наук. Наукову доповідь «Життя у минулому, сучасному та майбутньому: синхронізація повсякдення» виголосив О. Люфгрен (Університет Лунду, Швеція), зацікавивши присутніх несподіваною, але присутньою останнім часом у європейській культурології метафорою «валізи» як потрібного, але у чомусь і зайвого багажу, в яку людство намагається вмістити весь свій попередній та нинішній досвід. Висновок такого бачення зрозумілий - від непотрібного багажу, навіть якщо ми до нього звикли, необхідно відмовлятися.

Цікаву фольклорну програму з різних регіонів Хорватії представив відомий студентський культурно-художній гурт імені І.-Г. Ковачича, заснований ще 1948 р. Також у виконанні жіночого вокально-хореографічного ансамблю «Ethnotine», який творчо поєднує традиційні та сучасні фольклорні форми, було представлено короткі жартівливі пісні хорватських бечариів - традиційного фольклорного жанру, який у 2011 р. було включено до переліку нематеріальної культурної спадщини ЮНЕСКО.

Не $є$ можливим докладно зупинитися на насиченій, цікавій та різноплановій роботі майже двадцятьох секцій та панелей, адже сама програма та короткі резюме доповідей учасників конгресу, яких було понад сімсот, склали чималий збірник (186 стор.). При цьому, зауважимо, наукове звання доповідача та країну, яку він представляє, зазначати тут не прийнято, що відповідає демократичному принципу рівності наукової спільноти та єдності «європейського дому». Кожну секцію, або панель, було об'єднано певним «ключовим» словом, до того ж вони мали по декілька - яка більше, яка менше - окремих тем і відповідно засідань. Наприклад, «їжа» - 7, «тіло» - 6, «архіви» - 4, «гендер» - 6, «наративи» 8 засідань і т.д. Варто зазначити, що вже на етапі подання теми учасники надсилали свої пропозиції, маючи на увазі конкретну секцію, яку скликає модератор і яка водночас не може бути занадто переобтяженою, тому на кожному засіданні упродовж одного дня виголошується не більше десяти-одинадцяти двадцятихвилинних доповідей.

Зрозуміло, що однією з найпопулярніших виявилася секція, присвячена питанням матеріальної та нематеріальної культурної спадщини - цей блок нараховував 14 тематичних засідань, присвячених як теоретичним (зокрема, спадщина як складова європейської інтеграції; соціальні та економічні ресурси культурної спадщини; конфлікти та їхні наслідки; народне вбрання як вияв ідентичності; спадщина та замовчувана пам'ять тощо), так і суто практичним проблемам (політика ЮНЕСКО та менеджмент, пов'язаний із спадщиною; пам'ять та пошанування й т.ін.).

Міждисциплінарний підхід було продемонстровано, зокрема, під час обговорення теми «Від фольклору до нематеріальної культурної спадщини». Метою обговорення було привернути увагу до гносеологічних та методологічних меж понять «фольклор» і «культурна спадщина» 3 позицій антропології, етнології та культурології. На секції було виголошено шість доповідей, зокрема стосовно фольклорної імпровізації на прикладі киргизьких усних виконавців (М. Коскун, Інститут соціальної антропології імені Макса Планка), народного вбрання та традиційних атрибутів в українському поховальному обряді сумне весілля (О. Микитенко, Інститут мистецтвознавства, фольклористики та етнології імені М. Т. Рильського), проектів ЮНЕСКО із захисту нематеріальної культурної спадщини як «інструменту безперервного розвитку» (М. Куша), народних танців як традиції та культурної спадщини (М. Нільсон, Університет у Гетенбурзі), нових форм традиційної хореографії (Ю. Кью, Університет науки і технології у Гонг-Конгу), фольклору та культурної спадщини двох етнографічних осередків - у Молісі в Італії та Богемії у Чеській Республіці (А. Теста, Університет у Пардубіцях). 
3 упевненістю можна сказати, що на конгресі було охоплено максимально широке коло наукової проблематики - від питань соціально-політичних рухів, міграцій, релігійних течій тощо до проблем, пов'язаних із захистом тварин. При цьому не варто стверджувати, що інколи досить незвичні аспекти сучасної етнологічної наукової парадигми означали зміну існуючої. Як ми могли переконатися, змінюються акценти, увага більше зосереджується на тих питаннях, що раніше не були актуальними для науки, водночас різноманітний етнологічний матеріал вивчається під різним кутом зору, хоча переважно 3 позицій функціонального, або антропоцентричного аналізу, притаманному загалом сучасній гуманітаристиці.

Учасникам конгресу було запропоновано також цікаву культурну програму. Вони мали можливість ознайомитися з історичними і культурними пам'ятниками Загреба та здійснити екскурсійні поїздки Хорватією - до Істрії, Вараждина та національного парку-заповідника «Плитвицькі озера».

Роз'їжджалися учасники загребського конгресу етнологів із щирою подякою організаторам, яскравими враженнями від древнього міста та країни, збагачені новим досвідом та дружніми контактами і $з$ наміром за два роки зустрітися на наступному, XIII конгресі SIEF у Гейдельберзі.

${ }^{1}$ SIEF 2015 theme: Utopias, Realities, Heritages: Ethnographies for the $21^{\text {st }}$ century / Zagreb $12^{\text {th }}$ SIEF congress, 21-25 June 2015. - P. 9.

${ }^{2}$ Wolanik Boström K. Mobile Physicians Making Sense of Culture(s). On Mobile Everyday Ethnography / Katarzyna Wolanik Boström, Magnus Öhlander // Ethnologia Europaea. Journal of European Ethnology. - 2015. - Vol. 45. - Nr. 1. - P. 8.

${ }^{3} \dot{C}$ apo J. Ethnology and Anthropology in Europe/ Towards a Trans-National Discipline // What's in a Discipline? Special issue on the the occasion of the $50^{\text {th }}$ anniversary of the International Society for Ethnology and Folklore / Cultural analysis. An Interdisciplinary Forum on Folklore and Popular Culture. 2014. - Vol. 13. - P. 51. 